\title{
Retrospective study of the epidemiological overview of the transmission of Chagas disease in the State of Acre, South-Western Amazonia, from 2009 to 2016.
}

Open acess

${ }^{1}$ Programa de Pós Graduação Stricto Sensu em Ciência da Saúde na Amazônia Ocidental, Universidade Federal do Acre, Rio Branco, Acre, Brasil.

${ }^{2}$ Centro de Ciências da Saúde e do Desporto, Universidade Federal do Acre, Rio Branco, Acre, Brasil.

3Programa de Pós Graduação Stricto Sensu em Ciência, Inovação e Tecnologia para a Amazônia, Universidade Federal do Acre, Rio Branco, Acre, Brasil.

${ }^{4}$ Instituto Federal de Educação, Ciência e Tecnologia de Rondônia, Guajará Mirim, Rondônia, Brasil.

${ }^{5}$ Instituto de Educação, Agricultura e Ambiente da Universidade Federal do Amazonas, Humaitá, Amazonas, Brasil.

${ }^{6}$ Colégio de Aplicação, Universidade Federal do Acre, Rio Branco, Acre, Brasil.

Corresponding author: dionatas@icbusp.org

Manuscript received: April 2018 Manuscript accepted: October 2018 Version of record online: November 2018
Gerlandes Fernandes de Oliveira, Mariane Albuquerque Lima Ribeiro ${ }^{1,2}$, Gabriela Vieira de Souza Castro,,2, André Luiz Rodrigues Menezes ${ }^{3,4}$, Renato Abreu Lima ${ }^{5}$, Romeu Paulo Martins Silva ${ }^{1,2,3}$, Dionatas Ulises de Oliveira Meneguetti ${ }^{1,3,6}$

\begin{abstract}
Introduction: Chagas disease (CD), also known as American Trypanosomiasis, is an infectious parasitic disease caused by the etiologic agent Trypanosoma cruzi. It is considered endemic in the low-income population and is classified by the $\mathrm{WHO}$ as a neglected tropical disease. In the state of Acre, there is almost no scientific data regarding the epidemiology of $C D$, even though the first autochthonous case was registered in the 1980s.
\end{abstract}

Objective: To analyze the epidemiological panorama of the transmission of Chagas disease in the State of Acre, Brazil, from 2009 to 2016.

Methods: A survey of the occurrence of Chagas disease in the State of Acre was performed using public domain secondary data from the Brazil's Notifiable Diseases Information System of SUS (publicly funded health care system), and from the SUS Database of the Health Surveillance Foundation of the State of Acre. Data were collected from the following variables: gender, age group, form of contagion, distribution by region and municipality, perimeter and seasonality.

Result: Forty-two cases of CD were confirmed, with an increase of more than $300 \%$ from 2015 to 2016 and a frequency coefficient of 3.06 cases per 100,000 people, and in the Tarauacá/Envira region, the probability of a person contracting CD was $600 \%$ higher than the state mean.

Conclusion: We found that in the state of Acre, in the period from 2009 to 2016, most cases of CD occurred in 2016, in the Tarauacá/Envira region, mainly in the municipality of Feijó, in the rural zone, from July to October, in the age group of 0 to 30 years, being the oral form the main route of transmission and presenting no statistical difference between men and women.

Keywords: neglected diseases, American Trypanosomiasis, Amazon

Suggested citation: Oliveira GF, Ribeiro MAL, Castro GVS, Menezes ALR, Lima RA, Silva RPM, et al. Retrospective study of the epidemiological overview of the transmission of Chagas disease in the State of Acre, South-Western Amazonia, from 2009 to 2016. Journal of Human Growth and Development. 2018; 28(3):329-336. DOI: http://dx.doi.org/10.7322/jhgd.152187 


\section{INTRODUCTION}

Chagas disease (CD), also known as American Trypanosomiasis, is an infectious parasitic disease caused by the etiologic agent Trypanosoma cruzi ${ }^{1}$. This disease is widely disseminated in Latin America, being surpassed in numbers of cases by malaria alone ${ }^{2,3}$.

$\mathrm{CD}$ is considered endemic in the low-income population and is classified by the World Health Organization (WHO) as a neglected tropical disease, due to low investments in research, production of medication and prophylaxis ${ }^{1,4}$.

In the world, there is an estimation of approximately 6 and 7 million people infected with CD, especially in Latin America, whose expansion gradually affects more than 12 million individuals, reaching nonendemic countries in North America (United States and Canada), Europe (in particular Spain), Asia (Japan) and Oceania (Australia), increasing the number of people with Chagas disease living in non-endemic countries ${ }^{5}$.

The II Brazilian Consensus on CD estimated ${ }^{5}$, for 21 Latin American countries, based on 2010 data, that $5,742,167$ people were infected by T. cruzi, of which $3,581,423(62.4 \%)$ were residents of the countries of the Southern Cone Initiative, highlighting Argentina $(1,505,235)$, Brazil $(1,156,821)$, Mexico $(876,458)$ and Bolivia $(607,186)^{5,6}$.

In the Brazilian Amazon region, an increasing number of cases of acute and chronic CD have become evident in recent years, showing that $\mathrm{CD}$ is endemic throughout the Amazon region ${ }^{7-10}$, with a great variety of vectors ${ }^{11-18}$ and wild reservoirs ${ }^{19-22}$, providing a greater circulation of the etiological agent of the disease $^{7-10}$

In the Amazon region, the states with the highest number of $\mathrm{CD}$ case registers are Pará and Amazonas, with the main reasons for T. cruzi transmission being the construction of houses in rural locations near palm trees infested with triatomines and infected marsupials, associated with deforestation, which transforms the landscape and the biotope of the triatomines, allowing their invasion into the households ${ }^{23,24}$. The most frequent form of transmission is oral, mainly by the consumption of fruit juices and pulps, such as açaí and others from palm trees ${ }^{9,10,25-28}$.

In the state of Acre, there are almost no scientific data regarding the epidemiology of $\mathrm{CD}$; however, the first autochthonous case was already registered in the $80 \mathrm{~s}^{29}$, showing the potential for the occurrence of this disease in the state, which justified conducting this study, which aimed at analyzing the epidemiological panorama of the transmission of CD in the State of Acre, South-Western Amazonia, from 2009 to 2016.

\section{METHODS}

\section{Study Site}

The state of Acre is one of the 27 Federative Units of Brazil, located in the southwest of the North region, bordering the north of Amazonas and the east of Rondônia, in addition to international borders with Peru and Bolivia ${ }^{30}$. The state has approximately
$4 \%$ of the Brazilian Amazon area and $1.9 \%$ of the national territory, with a surface of $164,221.36 \mathrm{~km}^{2}$, and it is located at latitude $\left(7^{\circ} 06^{\prime} 56^{\prime \prime} \mathrm{N}\right)$ and longitude $\left(68^{\circ} 42 \text { '59"S }\right)^{30,31}$.

Acre is politically constituted by 22 Municipalities and divided into five development regions (Figure 1): Alto Acre, Baixo Acre, Purus, Tarauacá/Envira and Juruáa ${ }^{1,32}$.

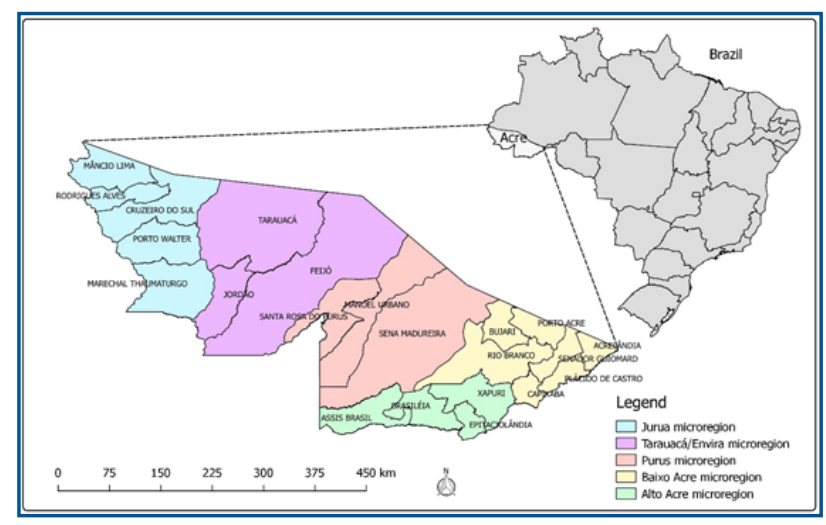

Figure 1: Map of the State of Acre distributed by Microregion

\section{Epidemiological Survey}

This was a retrospective and descriptive population study with the collection and analysis of data referring to the reported cases of T. cruzi infection in the state of Acre, secondary data from the Brazil's Notifiable Diseases Information System (SINAN) collected through the Brazil's Single Health System Database (DATASUS). These data were used to determine the frequency of infection and to identify the epidemiological profile of T. cruzi carriers.

The inclusion criteria were all the positive cases in years 2009 to 2016, variables such as gender, age and form of contagion (oral, vector and others), distributed by region, city, area (urban, rural and periurban), seasonality. The exclusion criteria in this study were the positive cases out of the research period and variables that are out of what was previously described.

\section{Statistical Analysis}

The Frequency Coefficient (number of Cases/ Population of the locality in the surveyed year $\times$ Base $100,000)$ was calculated. For the statistical analyses, the following tests were used: Kruskal-Wallis and student's t (GraphPad Prism 6.0 Software); Odds Ratio (Epi Info 7 Software), the data were organized in mean + standard deviation, being significant when $(\mathrm{p}<0.05)$.

\section{RESULTS}

It was possible to observe that from 2009 to 2016, an amount of 139 suspected cases of Chagas disease was registered, of which 97 reports were discarded and 42 were confirmed.

The year with the highest occurrence of CD was 2016, with 25 cases, which represented an increase of $316.67 \%$, compared to 2015 , which was the second year with the highest number of cases. Regarding the 
frequency coefficient, 2016 also presented the highest result, with 3.06 cases per 100,000 people (Table 1).

The reported cases occurred in three different regions, with the highest occurrence in the Tarauacá/ Envira region, followed by Juruá (Table 2).
In Table 2, the Odds Ratio calculation showed that in the Tarauacá/Envira region, the probability of a person contracting $\mathrm{CD}$ is $600 \%$ higher than the state mean.

In the Tarauacá/Envira region, the municipality

Table 1: Frequency Coefficient of Chagas disease in the State of Acre, from 2009 to 2016.

\begin{tabular}{lccc}
\hline Year & No. of cases & Population32 & Frequency Coefficient \\
\hline 2009 & 2 & 691,132 & 0.29 \\
2010 & 5 & 733,559 & 0.68 \\
2011 & 0 & 746,386 & 0 \\
2012 & 0 & 758,786 & 0 \\
2013 & 1 & 776,463 & 0.13 \\
2014 & 3 & 790,101 & 0.38 \\
2015 & 6 & 803,513 & 0.75 \\
2016 & 25 & 816,687 & 3.06 \\
Mean & 5.25 & 764,578 & 0.69 \\
\hline
\end{tabular}

Table 2: Number of cases of Chagas disease and Odds ratio, distributed by region of the state of Acre, from 2009 to 2016.

\begin{tabular}{lcc}
\hline Regions & No. of cases & Odds Ratio (95\%Cl) \\
\hline State of Acre & 42 & 1.0 (Reference) \\
Tarauacá/Envira Region & 29 & $7.10(4.42-11.39)^{\star}$ \\
Juruá Region & 12 & $1.60(0.84-3.05)$ \\
Baixo Acre Region & 1 & $0.04(0.01-0.30)^{\star}$ \\
\hline
\end{tabular}

* Significant

of Feijó was the one with the highest number of $\mathrm{CD}$ registered in the study period, followed by the municipalities of Rodrigues Alves, Mâncio Lima and Cruzeiro do Sul, belonging to the Juruá region (Table 3). Table 3 also shows seasonality data, and it is possible to observe that the period with the highest occurrence was from July to October of the years under study.

Among the forms of transmission, it was observed that $32(76.19 \%)$ of the cases occurred orally and $10(23.81 \%)$ by other transmission routes, being that the confirmation that registers related to the vector transmission were not available.

Regarding the distribution of the number of cases per zone, it was observed that the majority occurred in the rural zone, representing $88 \%$ of the cases, being this result significantly higher $(p<0.05)$ than the urban and peri-urban zones, as shown in (Table 4).

Table 3: Seasonal distribution of the number of Chagas disease cases in the municipalities of the State of Acre, from 2009 to 2016.

\begin{tabular}{|c|c|c|c|c|c|c|c|c|c|c|c|c|c|}
\hline Municipality & Jan & Feb & Mar & Apr & May & June & July & Aug & Sept & Oct & Nov & Dec & Total \\
\hline Cruzeiro do Sul & 0 & 0 & 1 & 0 & 0 & 0 & 0 & 1 & 0 & 0 & 1 & 0 & 3 \\
\hline Feijó & 0 & 0 & 0 & 0 & 1 & 0 & 11 & 1 & 6 & 5 & 1 & 0 & 25 \\
\hline Jordão & 0 & 0 & 0 & 0 & 0 & 0 & 0 & 0 & 0 & 2 & 0 & 0 & 2 \\
\hline Mâncio Lima & 1 & 0 & 0 & 0 & 0 & 0 & 0 & 0 & 1 & 1 & 0 & 0 & 3 \\
\hline Porto Walter & 0 & 0 & 0 & 0 & 0 & 0 & 0 & 0 & 0 & 1 & 0 & 0 & 1 \\
\hline Rio Branco & 0 & 0 & 0 & 0 & 0 & 0 & 0 & 0 & 0 & 0 & 0 & 1 & 1 \\
\hline Rodrigues Alves & 0 & 3 & 1 & 0 & 0 & 0 & 1 & 0 & 0 & 0 & 0 & 0 & 5 \\
\hline Tarauacá & 0 & 0 & 0 & 0 & 0 & 1 & 0 & 0 & 0 & 0 & 1 & 0 & 2 \\
\hline Total & 1 & 3 & 2 & 0 & 1 & 1 & 12 & 2 & 7 & 9 & 3 & 1 & 42 \\
\hline
\end{tabular}

Table 4: Distribution by zone of the number of Chagas disease cases occurring in the state of Acre, from 2009 to 2016.

\begin{tabular}{lcccccccccc}
\hline Zones & $\mathbf{2 0 0 9}$ & $\mathbf{2 0 1 0}$ & $\mathbf{2 0 1 1}$ & $\mathbf{2 0 1 2}$ & $\mathbf{2 0 1 3}$ & $\mathbf{2 0 1 4}$ & $\mathbf{2 0 1 5}$ & $\mathbf{2 0 1 6}$ & Total (\%) & Annual Mean $( \pm$ SD $)$ \\
Urban & 1 & 0 & 0 & 0 & 0 & 0 & 1 & 2 & $4(9.5 \%)$ & $0.50( \pm 0.70)$ \\
Rural & 1 & 5 & 0 & 0 & 1 & 3 & 4 & 23 & $37(88.1 \%)$ & $4.62( \pm 7.15)^{*}$ \\
Peri-urban & 0 & 0 & 0 & 0 & 0 & 0 & 1 & 0 & $1(2.4 \%)$ & $0.12( \pm 0.33)$ \\
Total & 2 & 5 & 0 & 0 & 1 & 3 & 6 & 25 & $42(100 \%)$ & $5.25( \pm 7.74)$ \\
\hline
\end{tabular}

* Kruskal-Wallis test $(p<0.05)$ 
The distribution by age group of the number of $\mathrm{CD}$ cases was evaluated, and it became evident that more than $80 \%$ of the cases occurred in the age range 0-30 years old, with 18 cases being $(42.86 \%)$ in the age group from 0 to 15 years, $17(40.48 \%)$ from 16 to 30 years, $4(9.52 \%)$ from 31 to 45 years, 1 (2.38\%) from 46 to 60 years and $2(4.76 \%) 60$ years or more.
Regarding the number of cases distributed by gender, there was a higher occurrence in men 25 $(59.5 \%$ - annual mean $3.12 \pm 3.98)$, than in women 17 (40.5\% - annual mean $2.12 \pm 3.82$ ); however, there was no statistical significance between the means $(\mathrm{p}>0.05$ Student's T-test) (Table 5).

Table 5: Number of Chagas disease cases, distributed by gender in the State of Acre, from 2009 to 2016.

\begin{tabular}{lcccccccccc}
\hline Gender & $\mathbf{2 0 0 9}$ & $\mathbf{2 0 1 0}$ & $\mathbf{2 0 1 1}$ & $\mathbf{2 0 1 2}$ & $\mathbf{2 0 1 3}$ & $\mathbf{2 0 1 4}$ & $\mathbf{2 0 1 5}$ & $\mathbf{2 0 1 6}$ & Total (\%) & Annual Mean (士SD) \\
\hline Men & 1 & 3 & 0 & 0 & 1 & 3 & 4 & 13 & $25(59.5 \%)$ & $3.12( \pm 3.98)$ \\
Women & 1 & 2 & 0 & 0 & 0 & 0 & 2 & 12 & $17(40.5 \%)$ & $2.12( \pm 3.82)$ \\
\hline Total & 2 & 5 & 0 & 0 & 1 & 3 & 6 & 25 & $42(100 \%)$ & $5.25( \pm 7.74)$ \\
\hline
\end{tabular}

Mean: Student's t-test $(p>0.05)$

\section{DISCUSSION}

In the Brazilian Amazonia, in recent years, a growing number of cases of CD have been occurring, reaffirming that this disease is endemic in the region ${ }^{10}$. This characteristic was also observed in the present study, in which it was verified that the years with the highest occurrence of CD were 2015 and 2016, with an increase in the number of cases between these two years of more than $300 \%$. A similar profile was observed by the Ministry of Health of Brazil from 2005 to 2010 , where there was an increase of more than 1000 cases of acute CD, of which 879 were concentrated in the Legal Amazon, where the state of the Acre is located ${ }^{10,33}$.

In the state of Acre, 2016 was also the year that presented the highest $\mathrm{CD}$ frequency coefficient with 3.06 cases per 100,000 people, which may still be underreported, since according to Teixeira et al. ${ }^{34}$, for every acute case detected in Amazonia, from 20 to 100 different cases were not reported, leading to an underestimation, increasing the negligence and severity of this disease in the region.

Even more worrying data were observed in the Tarauacá/Envira region, with an Odds Ratio seven times higher than the state mean, with the city of Feijó presenting the highest number of registers, accounting for $88.2 \%$ of $\mathrm{CD}$ cases of this region and $59.5 \%$ of state cases. The main source of agricultural produce of the municipality of Feijó is açaí, being the largest production of the state $^{35}$. These data may be related to the main transmission route occurring in the state during the study period, which was the oral transmission, with $76.2 \%$ of the cases. Similar results were observed by Pinto et al. ${ }^{7}$, who analyzed 233 cases of Chagas disease in the Amazon region from 1988 to 2005 and found that $78.5 \%$ of the cases were probably part of outbreaks caused by oral transmission.

Several studies show that most outbreaks of acute Chagas disease are associated with açaíi ${ }^{36-39}$, which is the main food responsible for the increase in the number of cases of Chagas disease in the North region in recent years, whether due to fruit or pulp contamination by means of waste from the infected triatomines in the endemic areas ${ }^{40}$, which have already been registered in the state with the occurrence of the following species: Rhodnius robustus ${ }^{29}$, Rhodnius pictipes $^{29}$, Rhodnius montenegrensis ${ }^{41}$, Rhodnius stali $^{16}$, Rhodnius neglectus ${ }^{42}$, Eratyrus mucronatus ${ }^{13}$, Panstrongylus geniculatus ${ }^{12}$, Panstrongylus megistus ${ }^{43}$ and Triatoma sordida ${ }^{44}$.

When the triatomine infected by T. cruzi or its waste is ground together with the açaí fruit at the time of preparation of the pulp, it favors the survival of the etiological agent for more than 48 hours at room temperature, 144 hours ( 6 days) at $4{ }^{\circ} \mathrm{C}$ and 26 hours at $-20^{\circ} \mathrm{C}^{45}$, with pasteurization being indicated as a safe way to eliminate the parasite ${ }^{46}$. However, pasteurization is not performed in most parts of the state of Acre, especially in the rural area, in which $88 \%$ of CD cases occurred, where açaí pulp is still handmade. Furthermore, in the rural area, some other aspects are described as facilitators for the occurrence of $\mathrm{CD}$, such as: construction of houses in rural areas near palm trees with the presence of triatomines and marsupials infected with T. cruzi; deforestation and proliferation of mammals, such as rodents and marsupials in degraded environments; intrusion of adult triatomines into households attracted by electric lighting or oil lamps ${ }^{10}$, all of which are observed in rural areas of the state of Acre.

When evaluating the seasonal distribution, it was possible to observe a higher occurrence of CD cases in the months of July to October, which represented $71.4 \%$ of the cases registered in the present study. This fact confirms the studies carried out in the state of Pará by Pinto et al. ${ }^{7}$, where this seasonality coincides with the açaí crop that reaches its maximum production between the months of June and December ${ }^{47}$, data that meet with the main route of "oral" transmission.

The açaí harvest is carried out mainly by youngsters and adults under 30 years old, due to the difficulty of climbing the palm trees, which is in agreement with the data of the present study, in which the age range from 0 to 30 years old was the one that presented the highest frequency of the disease, with $83.3 \%$ of the cases.

This characteristic may have a relation to the work of family subsistence of these localities, since these families depend almost exclusively on the agricultural activity and extractivism, living amid precarious conditions of basic sanitation ${ }^{48-50}$. 
Concerning the number of cases distributed by gender, there was no statistical difference between men and women. Studies show that there is no correlation between gender and serology for Chagas disease, since it affects both genders indistinctly ${ }^{51}$.

It was verified that in the state of Acre in the period from 2009 to 2016 , the majority of cases of CD occurred in 2016, in the Tarauacá/Envira region, mainly in the municipality of Feijó, in the rural area, from July to October, in the age group of 0 to 30 years old, being the oral form the main route of transmission and presenting no statistical difference between men and women.

\section{Acknowledgments}

Conselho Nacional de Desenvolvimento Científico e Tecnológico (CNPQ) Chamada Universal MCTI/CNPQ No 01/2016;

Fundação de Amparo à Pesquisa do Estado do Acre (FAPAC). Programa Pesquisa Para o SUS: Gestão Compartilhada em Saúde (PPSUS) 002/2016;

Pró-Reitoria de Pesquisa e Pós-Graduação da Universidade Federal do Acre (UFAC).

\section{REFERENCES}

1. Coura JR, Viñas PA. Chagas disease: a new worldwide challenge. Nature. 2010;465(7301):S6-7. DOI: https://dx.doi.org/10.1038/nature09221

2. Galvão C, Paula AS. Sistemática e evolução dos vetores. In: Galvão C. Vetores da doença de Chagas no Brasil. Curitiba: Sociedade Brasileira de Zoologia, 2015; p.26-31.

3. Barbosa-Silva AN, Câmara ACJ, Martins K, Nunes DF, Oliveira PIC, Azevedo PRM, et al. Characteristics of Triatomine infestation and natural Trypanosoma cruzi infection in the State of Rio Grande do Norte, Brazil. Rev Soc Bras Med Trop. 2016;49(1):57-67. DOI: http://dx.doi.org/10.1590/0037-8682-0300-2015

4. Santos CV, Bedin C, Wilhelms TS, Villela MM. Assessment of the Housing Improvement Program for Chagas Disease Control in the Northwestern municipalities of Rio Grande do Sul, Brazil. Rev Soc Bras Med Trop. 2016;49(5):572-8. DOI: http://dx.doi.org/10.1590/0037-8682-0386-2016

5. Dias JCP, Ramos Jr. AN, Gontijo ED, Luquetti A, Shikanai-Yasuda MA, Coura J R, et al. II Consenso Brasileiro em Doença de Chagas 2015. Epidemiol Serv Saúde. 2016;25(spe):7-86. DOI: http://dx.doi.org/10.5123/s1679-49742016000500002

6. World Health Organization (WHO). Chagas disease in Latin America: an epidemiological update based on 2010 estimates. Wkly Epidemiol Rec. 2015;90(6):33-43.

7. Pinto AYN, Valente SA, Valente VC, Ferreira Júnior AG, Coura JR. Fase aguda da doença de Chagas na Amazônia brasileira: estudo de 233 casos do Pará, Amapá e Maranhão observados entre 1988 e 2005. Rev Soc Bras Med Trop. 2008;41(6):602-14. DOI: http://dx.doi.org/10.1590/S0037-86822008000600011

8. Magalhães BML, Coelho LIARC, Maciel MG, Ferreira JMBB, Umezawa ES, Coura JR, et al. Serological survey for Chagas disease in the rural areas of Manaus, Coari, and Tefé in the Western Brazilian Amazon. Rev Soc Bras Med Trop. 2011;44(6):697-702. DOI: http://dx.doi.org/10.1590/S0037-86822011000600009

9. Coura JR, Junqueira ACV. Risks of endemicity, morbidity and perspectives regarding the control of Chagas disease in the Amazon Region. Mem Inst Oswaldo Cruz. 2012;107(2):145-54. DOI: http://dx.doi.org/10.1590/S0074-02762012000200001

10. Barbosa MGV, Ferreira JMBB, Arcanjo ARL, Santana RAG, Magalhães LKC, Mota DT, et al. Chagas disease in the State of Amazonas: history, epidemiological evolution, risks of endemicity and future perspectives. Rev Soc Bras Med Trop. 2015;48(Suppl 1):27-33. DOI: http://dx.doi.org/10.1590/0037-8682-0258-2013

11. Meneguetti DUO, Trevisan O, Rosa RM, Camargo LMA. First report of Eratyrus mucronatus, Stal, 1859, (Hemiptera, Reduviidae, Triatominae), in the State of Rondônia, Brazil. Rev Soc Bras Med Trop. 2011;44(4):511-2. DOI: http://dx.doi.org/10.1590/S0037-86822011000400022

12. Gurgel-Gonçalves R, Galvão C, Costa J, Peterson AT. Geographic Distribution of Chagas Disease Vectors in Brazil Based on Ecological Niche Modeling. J Trop Med. 2012;705(326):1-15. DOI: http://dx.doi.org/10.1155/2012/705326

13. Obara MT, Barata JMS, Rosa JA, Ceretti JW, Almeida PS, Gonçalves GA, et al. Description of the female and new records of Triatoma baratai Carcavallo \& Jurberg, 2000 (Hemiptera, Reduviidae) from Mato Grosso do Sul, Brazil, with a key to the species of the Triatoma matogrossensis subcomplex. Zootaxa. 2012;3151:63-8. DOI: http://dx.doi.org/10.5281/zenodo.210336

14. Galvão C. Vetores da doença de Chagas no Brasil. Curitiba: Sociedade Brasileira de Zoologia, 2014.

15. Jurberg J, Rodrigues JMS, Moreira FFF, Dale C, Cordeiro IRS, Lamas JRVD, et al. Atlas Iconográfico dos triatomíneos do Brasil: vetores da doença de Chagas. Rio de Janeiro: Fiocruz, 2014. 
16. Meneguetti DUO, Castro GVS, Castro MALR, Souza J L, Oliveira J, Rosa JA, et al. First report of Rhodnius stali (Hemiptera, Reduviidae, Triatominae) in the State of Acre and in the Brazilian Amazon. Rev Soc Bras Med Trop. 2016;49(3):365-8. DOI: http://dx.doi.org/10.1590/0037-8682-0066-2016

17. Terassini FA, Stefanello C, Camargo LMA, Meneguetti DUO. First report of Panstrongylus lignarius, Walker, 1873 (Hemiptera, Reduviidae, Triatominae), in the State of Rondônia, Brazil. Rev Soc Bras Med Trop. 2017;50(4):547-9. DOI: http://dx.doi.org/10.1590/0037-8682-0048-2017

18. Brito RN, Gorla DE, Diotaiuti L, Gomes ACF, Souza RCM, Abad-Franch F. Drivers of house invasion by sylvatic Chagas disease vectors in the Amazon-Cerrado transition: A multi-year, state-wide assessment of municipality-aggregated surveillance data. PLoS Negl Trop Dis. 2017; 11(11):e0006035. DOI: https://dx.doi.org/10.1371/journal.pntd.0006035

19. Araújo VA, Boité MC, Cupolillo E, Jansen AM, Roque AL. Mixed infection in the anteater Tamandua tetradactyla (Mammalia: Pilosa) from Pará State, Brazil: Trypanosoma cruzi, T. rangeli and Leishmania infantum. Parasitology. 2013;140(4):455-60. DOI: https://dx.doi.org/10.1017/S0031182012001886

20. Lima VS, Xavier SC, Maldonado IF, Roque AL, Vicente AC, Jansen AM. Expanding the knowledge of the geographic distribution of Trypanosoma cruzi Tcll and TcV/TcVI genotypes in the Brazilian Amazon. PLoS Negl Trop Dis. 2014;9(12):e116137. DOI: https://dx.doi.org/10.1371/journal.pone.0116137

21. Barros JHS, Xavier SCC, Bilac D, Lima VS, Dario MA, Jansen AM. Identification of novel mammalian hosts and Brazilian biome geographic distribution of Trypanosoma cruzi Tclll and TcIV. Acta Trop. 2017;172:173-9. DOI: https://dx.doi.org/10.1016/j.actatropica.2017.05.003

22. Santos FCB, Lisboa CV, Xavier SCC, Dario MA, Verde RS, Calouro AM, et al. Trypanosoma sp. diversity in Amazonian bats (Chiroptera; Mammalia) from Acre State, Brazil. Parasitology. 2017:1-10. DOI: https://dx.doi.org/10.1017/S0031182017001834

23. Dias JCP, Vinhaes MC, Silveira AC, Schofield CJ, Cardoso B, Coura JR. Pesquisas prioritárias dobre doença de Chagas na Amazônia: agenda de curto-médio prazo. Rev Soc Bras Med Trop. 2001;34(5):497-8. DOI: http://dx.doi.org/10.1590/S0037-86822001000500017

24. Dias JCP, Prata A, Schofield JC. Doença de Chagas na Amazônia: esboço da situação atual e perspectiva de prevenção. Rev Soc Bras Med Trop. 2002;35(6):669-78. DOI: http://dx.doi.org/10.1590/S0037-86822002000600021

25. Coura JR, Pereira JB. Chagas disease. What is known and what should be improved: a systemic review. Rev Soc Bras Med Trop. 2012;45(3):286-96. DOI: http://dx.doi.org/10.1590/S0037-86822012000300002

26. Souza-Lima RC, Barbosa MGV, Coura JR, Arcanjo ARL, Nascimento AS, Ferreira JMBB, et al. Outbreak of acute Chagas disease associated with oral transmission in the Rio Negro region, Brazilian Amazon. Rev Soc Bras Med Trop. 2013;46(4):510-4. DOI: http://dx.doi.org/10.1590/0037-8682-1367-2013

27. Coura JR. The main sceneries of Chagas disease transmission. The vectors, blood and oral transmissions - A comprehensive review. Mem Inst Oswaldo Cruz. 2015;110(3):277-82. DOI: http://dx.doi.org/10.1590/0074-0276140362

28. Costa EG, Santos SO, Sojo-Milano M, Amador EC, Tatto E, Souza DS, et al. Acute Chagas Disease in the Brazilian Amazon: Epidemiological and clinical features. Int J Cardiol. 2017;15(235):176-8. DOI: https://doi.org/10.1016/j.ijcard.2017.02.101

29. Barata JMS, Rocha RM, Rodrigues FFNA. Primeiro caso autóctone de tripanossomíase americana do estado do Acre (Brasil) e sua correlação com as cepas isoladas do caso humano e de triatomíneos silvestres da área. Rev Saúde Pública. 1988;22(5):401-10. DOI: http://dx.doi.org/10.1590/S0034-89101988000500005

30. Instituto Brasileiro de Geografia e Estatística (IBGE). Panorama Populacional do Acre. [cited 2018 Fev 06] Available from: https://cidades.ibge.gov.br/brasil/ac/panorama.

31. Zoneamento Ecológico Econômico do Acre (ZEE). Uso da terra acreana com sabedoria: Resumo educativo: fase II (escala 1: 250.000) Rio Branco: Secretaria de Estado de Meio Ambiente do Acre, 2010.

32. Acre. Governo do Estado do Acre. Acre em números 2017: Rio Branco: SEPLAN. 2017.

33. Ostermayer A, Passos A, Silveira A, Ferreira A, Macedo V, Prata A. O inquérito nacional de soroprevalência de avaliação do controle da doença de Chagas no Brasil (2001-2008). Rev Soc Bras Med Trop. 2011;44(supl 2):108-21. DOI: http://dx.doi.org/10.1590/S0037-86822011000800015

34. Teixeira ARL, Monteiro OS, Rebelo JM, Argañaraz ER, Vieira D, Lauria-Pires L, et al. Emerging Chagas disease: trophic network and cycle of transmission of Trypanosoma cruzi from palm trees in the Amazon. Emerg Inf Dis. 2001;7(1):100-12. DOI: http://dx.doi.org/10.3201/eid0701.700100 
35. Maciel RCG, Penha DDLB, Cavalcante Filho PG, Souza DL, Silva PA, Santos FSL. Desenvolvimento rural, agricultura familiar e os produtos florestais não madeireiros: o caso do açaí na região de Feijó, Estado do Acre. Rev Econ Agríc. 2014;61(1):5-21.

36. Pinto AYN, Harada G, Valente SAS, Valente VC, Araújo JEA, Gomes FS. Cardiopatia chagásica aguda em microepidemia familiar em Abaetetuba, PA. XXXV Congresso da Sociedade Brasileira de Medicina Tropical, 1999.

37. Pantoja RKS, Leite MAO, Pauxis BT, Pinto AYN, Valente SAS, Valente VC. Relato de três casos autóctones de doença de Chagas aguda no Estado do Pará. XXXVI Congresso da Sociedade Brasileira de Medicina Tropical, 2000.

38. Miles MA. Orally acquired Chagas disease: lessons from an urban school outbreak. J. infect. Dis. 2010;201(9):1282-4. DOI: https://doi.org/10.1086/651609

39. Nóbrega AA, Garcia MH, Tatto E, Obara MT, Costa E, Sobel J, et al. Oral transmission of Chagas disease by consumption of açaí palm fruit, Brazil. Emerg Infect Dis. 2009;15(4):653-5. DOI: https://dx.doi. org/10.3201/eid1504.081450

40. Ferreira RTB, Branquinho MR, Leite PC. Transmissão oral da doença de Chagas pelo consumo de açaí: um desafio para a Vigilância Sanitária. Vig Sanit Debate. 2014;2(4):4-11. DOI: https://dx.doi.org/10.3395/ VD.V214.358

41. Meneguetti DUO, Tojal SD, Miranda PRM, Rosa JA, Camargo LMA. First report of Rhodnius montenegrensis (Hemiptera, Reduviidae, Triatominae) in the State of Acre, Brazil. Rev Soc Bras Med Trop. 2015;48(4):471-3. DOI: http://dx.doi.org/10.1590/0037-8682-0029-2015

42. Ramos LJ, Castro GVS, Souza JL, Oliveira J, Rosa JA, Camargo LMA, et al. First report of Rhodnius neglectus, Lent, 1954 (Hemiptera, Reduviidae, Triatominae) in the State of Acre and in the Brazilian western Amazon. Rev Soc Bras Med Trop. 2018;51(2):212-4. DOI: http://dx.doi.org/10.1590/0037-8682-0320-2017

43. Castro MALR, Castro GVS, Souza JL, Souza CR, Ramos LJ, Oliveira J, et al. First report of Panstrongylus megistus (Hemiptera, Reduviidae,Triatominae) in the State of Acre and Rondônia, Amazon, Brazil. Acta Trop. 2018;182:158-60. DOI: http://dx.doi.org/0.1016/j.actatropica.2018.02.032

44. Ramos LJ, Souza JL, Souza CR, Oliveira J, Rosa JA, Camargo LMA, et al. First report of Triatoma sordida, Stål, 1859 (Hemiptera, Reduviidae, Triatominae) in the State of Acre and in the Brazilian western Amazon. Rev Soc Bras Med Trop. 2018;51(1):77-9. DOI: http://dx.doi.org/10.1590/0037-8682-0161-2017

45. Passos LAC, Guaraldo AMA, Barbosa RL, Dias VL, Pereira KS, Schmidt FL, et al. Sobrevivência e infectividade do Trypanosoma cruzi na polpa de açaí: estudo in vitro e in vivo. Epidemiol Serv Saúde. 2012;21(2):223-32. DOI: http://dx.doi.org/10.5123/S1679-49742012000200005

46. Labello BR, Dias VL, Pereira KS, Schmidt FL, Franco RMB, Guaraldo AMA, et al. Survival in vitro and virulence of Trypanosoma cruzi in açaí pulp in experimental acute Chagas disease. J Food Prot. 2012;75(3):601-6. DOI: http://dx.doi.org/10.4315/0362-028X.JFP-11-233

47. Rogez H. Açaí: preparo, composição e melhoramento da conservação. Belém: Edufpa, 2000.

48. Coura JR, Transmissão da infecção chagásica por via oral na história natural da doença de Chagas. Rev Soc Bras Med Trop. 2006;39(Suppl 3):113-7. DOI: http://dx.doi.org/10.1590/0037-8682

49. Fuente CAL, Minoli SA, Lopes CM, Noireau F, Lazzari CR, Lorenzo MG. Flight dispersal of the Chagas Disease Vectors Triatoma brasiliensis and Triatoma pseudomaculata in Northeastern Brazil. Acta Trop. 2007;101(2):115-9. DOI: https://dx.doi.org/10.1016/j.actatropica.2006.12.007

50. Silva MBA, Barreto AVMS, Silva HA, Galvão C, Rocha D, Jurberg J, et al. Synanthropic triatomines (Hemiptera, Reduviidae) in the state of Pernambuco, Brazil: geographical distribution and natural Trypanosoma infection rates between 2006 and 2007. Rev Soc Bras Med Trop. 2012;45(1):60-5. DOI: http://dx.doi.org/10.1590/S0037-86822012000100012

51. Moraes-Souza H, Martins PRJ, Pereira GA, Ferreira-Silva MM, Abud MB. Perfil sorológico para doença de Chagas dos doadores de sangue do Hemocentro Regional de Uberaba. Rev Bras Hematol Hemoter. 2006;28(2):110-4. DOI: http://dx.doi.org/10.1590/S1516-84842006000200009 


\section{Resumo}

Introdução: A doença de Chagas (DC), também conhecida como Tripanossomíase Americana, é uma doença infecciosa e parasitária, causada pelo agente etiológico Trypanosoma cruzi, sendo considerada endêmica em população de baixa renda e classificada pela Organização Mundial da Saúde como uma doença tropical negligenciada. No estado do Acre, quase não há dados científicos sobre a epidemiologia da DC, embora o primeiro caso autóctone tenha sido registrado na década de

1980.

Objetivo: Analisar o panorama epidemiológico da transmissão da DC no Estado do Acre, no período de 2009 a 2016.

Método: O levantamento da ocorrência da DC no Estado do Acre foi realizado utilizando dados secundários de domínio público do Sistema de Informação de Agravos de Notificação do SUS e do Banco de Dados do SUS da Fundação de Vigilância Sanitária do Estado do Acre. Foram coletados dados das seguintes variáveis: sexo, faixa etária, forma de contágio, distribuição por região e município, perímetro e sazonalidade.

Resultado: Quarenta e dois casos de DC foram confirmados, com um aumento de mais de $300 \%$ de 2015 a 2016 e um coeficiente de frequência de 3,06 casos por 100.000 pessoas, e na região de Tarauacá / Envira, a probabilidade de uma pessoa contrair CD foi de $600 \%$ maior que a média do estado.

Conclusão: Constatamos que no estado do Acre, no período de 2009 a 2016, a maioria dos casos de DC ocorreu em 2016, na região de Tarauacá/Envira, principalmente no município de Feijó, na zona rural, de julho a outubro, em faixa etária de 0 a 30 anos, sendo a via oral a principal via de transmissão e sem diferença estatística entre homens e mulheres.

Palavras-chave: doenças negligenciadas, tripanossomíase americana, Amazônia. 